\title{
Nutritional Content and Health Benefits of Bangladeshi Eggplant Cultivars
}

\author{
A. K. M. Quamruzzaman, Anjumanara Khatun, Ferdouse Islam
}

\begin{abstract}
The investigation was conducted at the Olericulture Division, Bangladesh Agricultural Research Institute and the laboratory work was done at Vegetable Research Technology Section, Institute of Food Science and Technology, Bangladesh Council of Scientific and Industrial Research, Dhaka, Bangladesh during 2019-20 with ten types (Six- OP, four- Hybrid) of eggplant cultivar viz., BARI Begun4, BARI Begun-6, BARI Begun- 8, BARI Begun-10, BARI Hybrid Begun-2, BARI Hybrid Begun-4, SM233, SM275, Hybrid 5x216 and Hybrid 21x11 to study the nutritional composition and its human health benefit. Eggplant is ranked amongst the most top ten vegetables that provide the healthiest food with low calories and also contain high phenolic contents that are helpful in radical absorbing capacity. Each vegetable contains a unique amount of various nutrients that are strongly linked with the protection of different health diseases. There were no significant differences among the six OP and four hybrid cultivars regarding yield. Fruit yield was more or less the same but the main differences were in fruit size and color as well as fruit shape. We got the moisture content (91.39-94.87\%, crude fiber $(1.01-2.48 \%)$, ash $(0.37-0.62 \%)$, protein $(0.85-1.54 \%)$, fat $(0.02-0.4 \%)$, carbohydrate $(4.27-$ $6.63 \%)$, energy $(19.59-32.1 \mathrm{Kcal})$, sugar $(0.48-1.38 \%)$, ascorbic acid (6.57-17.21 mg 100g-1), anthocyanin (6.31-78.51 mg C3GE $\left.100 \mathrm{~g}^{-1}\right)$. Significant amount of mineral were present in eggplant cultivars viz., $K\left(122.38-162.27 \mathrm{mg}^{100 \mathrm{~g}^{-1}}\right)$, Na (4.06-

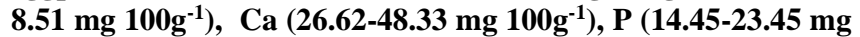

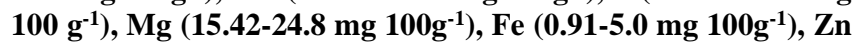

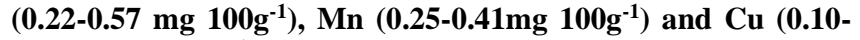
$\left.0.16 \mathrm{mg} 10 \mathrm{0g}^{-1}\right)$. These nutritional amounts will able to provide a significant amount of nutrition to the human body for the proper growth. These compounds were found helpful in the cure of various diseases like cancer, anti-inflammatory, anti-asthmatic, anti-platelet hypo-lipidemic, and hypotensive, etc. Today most modern scientific techniques are available to cure different various health problems but still majority of the population across the globe depends upon the vegetables sources nutritious food.
\end{abstract}

Index Terms - Nutritional content, Health benefits, Bangladesh, Eggplant cultivars, Solanum melongena L.).

\section{INTRODUCTION}

Eggplant (Solanum melongena L.) is a popular vegetable in Bangladesh as well as the sub-continent of South East Asia along with the Mediterranean area. It belongs to a family Solanaceae and is an economically important

Published on July 21, 2020.

A. K. M. Quamruzzaman, Bangladesh Agricultural Research Institute, Bangladesh.

(corresponding e-mail: akmqzs ${ }^{\circledR}$ gmail.com)

A. Khatun, Institute of Food Science and Technology, Bangladesh. (e-mail: anjuzamanmmm ${ }^{@}$ gmail.com)

F. Islam, Bangladesh Agricultural Research Institute, Bangladesh. (e-mail: ive_bari@yahoo.com) vegetable crop. Fruit from eggplant is available in the market throughout the year as it is generally grown twice or thrice in a year. Eggplant is shown a variety of shapes (egg to long club-shaped) and colors occur from white, green, yellowish, different color s of purple, black color [60]. Eggplants fruit is very nutritious and uses for medicinal purposes due to its composition, which includes has very low calories with good minerals like potassium, calcium, magnesium, sodium, iron, and phytochemicals that contain phenolic components (caffeine and chlorogenic acid), flavonoids, mainly nasunin. [36], [49] as well as dietary fiber that is helpful for our health [51], [63]. Fruits and vegetables are the main dietary sources of phenolic compounds for humans, with phenolic acids and flavonoids being the most abundant [34], [52]. Eggplant has very low calories in its fruit with good mineral content that is helpful for our health. Eggplant is ranked amongst the most top ten vegetables that provide the healthiest food with low calories and also contain high phenolic contents that are helpful in radical absorbing capacity [7], [8].

A wide range of secondary metabolites along with primary metabolites is producing by plants that influence human nutrition and health as well [30]. Primary metabolites are proteins, vitamins, lipids, and carbohydrates, etc. which mainly involved in developmental and physiological developments of plants that are also vital in our diet [57]. Secondary metabolites are those phytochemicals that often play a crucial role against different stresses but are not important for the basic processes of the plant [57]. Moreover, these phytochemicals are a vital basis for various medicines and the pharmaceutical industry, even recent modern and traditional remedies mainly depend on these phytochemicals [58]. Vegetables are excellent sources of such compounds that constitute the main portion of our diet and consider as a major source of vitamins (A, B complex (B1, B6, B9) and E), dietary fiber, minerals, and phytochemicals [48], [66].

Intake of vegetables in our daily diet results with over-all good health impact, reduction in gastrointestinal problems, improvement in vision and also playing an important role to reduce danger for various systems of cardiovascular problems, cancer, diabetes, stroke, anemia, gastric ulcer and other long-lasting disorders [21]. Lower risk of cardiovascular diseases in humans strongly associated with a high intake of vegetable diet [37]. According to the World Health Report, each year 2.7 million death causes because of a diet poor in vegetable consumption and with a stumpy intake of dietary fiber, carbohydrates, and proteins [12]. A survey carried out regarding world vegetable cultivation showed that around 402 vegetables are cultivated across the globe, characterize 69 families, and 230 genera [29]. Leafy vegetables (both leaves or fresh leaves) are utilized were the most frequently consumed (53\% of the total), trailed by 
vegetable with below ground edible portions covered $17 \%$ and then by vegetable fruits (15\%) [28], [29].

Eggplant cultivars produce fruits with a wide diversity of shapes, sizes, and colors [26], [27]. Also shown a variety of shapes (egg to long club-shaped) and colors occurs from white, green, yellowish, through grades of purple pigment to almost black color [60]. Various forms, colors, and shapes of eggplant are found throughout Southeast Asia, suggesting that this area is an important center of variation and possibly of origin. [64] suggested that its center of origin was in the Indo-Burma region. It is extensively grown in Bangladesh, India, Pakistan, Nepal, China, Japan, and the Philippines. We think different types of eggplant will contain different nutritional quality as well the physiological characteristics. So it is necessary to study the individual eggplant cultivar for their nutrition status. This work aimed to study the morphological characteristics, nutritional composition, and compare the proximal composition, mineral content, and antioxidant bioactive compounds of the popular eggplant cultivar in Bangladesh.

\section{MATERIALS AND METHODOLOGY}

\section{A. Experimental site}

The investigation was conducted at the Olericulture Division of Horticulture Research Centre, Bangladesh Agricultural Research Institute (BARI), and the laboratory work was done at Vegetable Research Technology Section, Institute of Food Science and Technology, Bangladesh Council of Scientific and Industrial Research, Dhaka, Bangladesh during 2019-20. The experimental field was at $23.9920^{\circ} \mathrm{N}$ Latitude and $90.4125^{\circ} \mathrm{E}$ Longitudes having an elevation of $8.2 \mathrm{~m}$ from sea level under agro-ecological zone (AEZ) 28 [3]. The experimental site is situated in the sub-tropical climatic zone and characterized by scanty rainfall during the experimental time. The average minimum and maximum temperature were $18.37^{\circ} \mathrm{C}$ and $29.37^{\circ} \mathrm{C}$.

\section{B. Plant materials}

Ten types of eggplant cultivar viz., BARI Begun-4, BARI Begun-6, BARI Begun- 8, BARI Begun-10, BARI Hybrid Begun-2, BARI Hybrid Begun-4, SM233, SM275, Hybrid 5x216 and Hybrid 21x11 were used in this study (Fig. 1).

\section{Sample preparation}

Eggplant fruits from the representative ten types of cultivar viz., BARI Begun-4, BARI Begun-6, BARI Begun8, BARI Begun-10, BARI Hybrid Begun-2, BARI Hybrid Begun-4, SM233, SM275, Hybrid 5x216 and Hybrid 21x11 were used in this study (Fig. 1). Fruit samples of each eggplant cultivar were harvested at the commercial mature stage from the experimental farm of Olericulture Division, Horticulture Research Centre, Bangladesh Agricultural Research Institute (BARI) during 2019-20 (23.9920 $\mathrm{N}$ Latitude and $90.4125^{\circ}$ E Longitudes), washed and sorted by color and size and divided into two groups. The first group was used fresh for proximate and mineral analysis, while the second group was freeze-dried and stored at $-80{ }^{\circ} \mathrm{C}$, for further evaluations of ascorbic acid and anthocyanin.

\section{Estimation of nutrients}

Moisture, ash, protein ( $\mathrm{N} \times 6.25)$, crude fiber, fat, and carbohydrates (by difference) contents were determined according to AOAC methods [4]. The mineral analysis was also done based on AOAC methods [4]. Potassium (K), sodium $(\mathrm{Na})$, calcium $(\mathrm{Ca})$, magnesium $(\mathrm{Mg})$, iron $(\mathrm{Fe})$, zinc $(\mathrm{Zn})$, copper $(\mathrm{Cu})$ and manganese $(\mathrm{Mn})$ were determined by atomic absorption spectroscopy using a Varian SpectrAA 220. Phosphorus (P) was determined colorimetrically at $650 \mathrm{~nm}$ in a Varian Cary E1 UV-Vis spectrophotometer.

Ascorbic acid extraction was done according to [42] with little bit modification as described by [40]. Ascorbic acid was quantified according to [13] using a Varian Pro Star 330 photodiode array detector HPLC system and a Varian Bondesil NH2 column (250 x $4.6 \mathrm{~mm})$. Results were expressed in milligrams per 100 grams of eggplant on a fresh basis.

Total anthocyanin was determined using a spectrophotometric method adapted from [1]. Anthocyanin content was calculated as the concentration of total anthocyanin, expressed as $\mathrm{mg}$ of cyanidin-3-glucoside equivalents per $100 \mathrm{~g}$ of sample (mgC3GE 100g-1).

E. Statistical analysis

ANOVA was used to assess statistical differences among eggplant types with a 5\% confidence level. When a significant difference was found, Tukey's multiple range tests were carried out to separate means using MSTAT-C. Data were expressed as means values of three samples.

\section{DISCUSSION}

\section{A. Morphological characteristics of eggplant}

In our morphological characteristics study, we evaluated ten eggplant cultivars of Bangladesh including six OP and four hybrid cultivars. We evaluated the horticultural characters [earliness (days to $1^{\text {st }}$ harvest), fruit shape, fruit color, fruit length $(\mathrm{cm})$, fruit diameter $(\mathrm{cm})$, individual fruit weight (g) and fruit no/ plant, fruit yield]. Considering the mentioned traits, we got BARI Begun-6, BARI Begun-8, BARI Begun-10, SM275, BARI Hybrid Begun-4 and Hybrid 21x11 were superior compare to other cultivars (Table 1). There were no significant differences among the OP and hybrid cultivars regarding yield. Fruit yield was more or less same but main differences were in fruit size and color as well fruit shape.

\section{B. Nutritional composition of eggplant}

Eggplants fruit is very nutritious and uses for medicinal purposes due to its composition, which includes has very low calories with good minerals like potassium, calcium, magnesium, sodium, iron, and phytochemicals that contain phenolic components (caffeine and chlorogenic acid), flavonoids, mainly nasunin. [36], [49] as well as dietary fiber that is helpful for our health [51], [63].

Generally we familiar with eggplants that are large and dark purple or oval green. But the shape, size, and color can vary from small and oblong to long and thin and from shades of purple to white or green. So, this interpretation will focus on the nutritional benefits of the traditional purple and green colored long and oval-shaped eggplant.

Considering the above fact, we have some nutritional composition analysis of popular eggplant cultivars in Bangladesh. Due to laboratory limitations, we have done the following analysis and got the results as follows. Moisture content was 91.39-94.87\% (Table 2), while [17, 35,38 ] got the moisture content 91.8 to $94.2 \%$, while Nino- 
Medina et al., 2014 reported little bit less with the value 90.10 to $92.70 \%$.

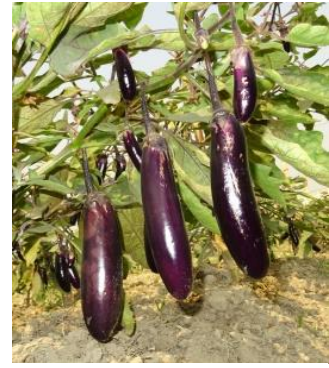

BARI Begun-4

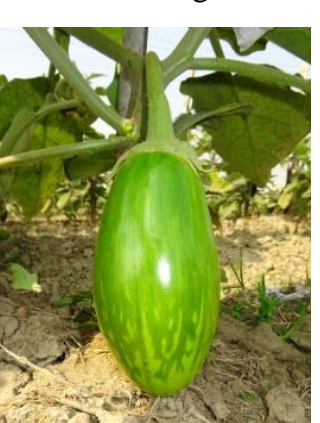

SM275

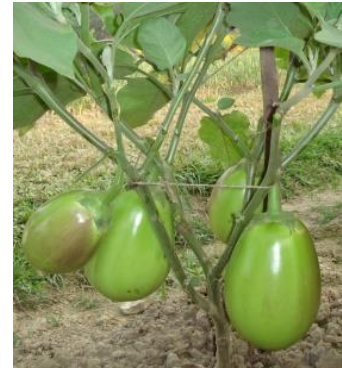

BARI Begun-6

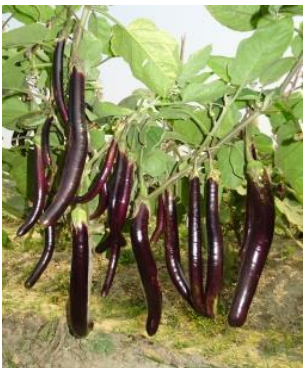

BARI Begun-8

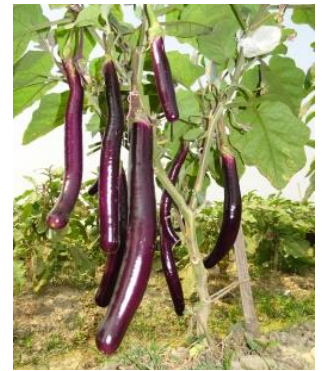

BARI Begun-10

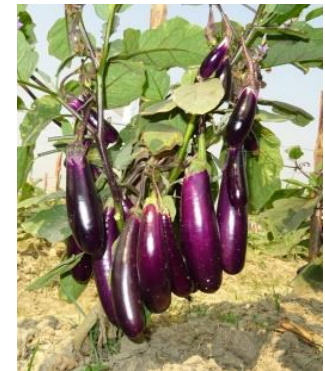

SM233

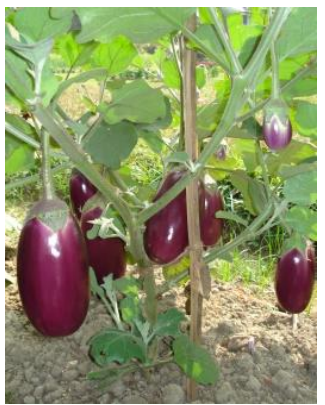

BARI Hybrid Begun-2

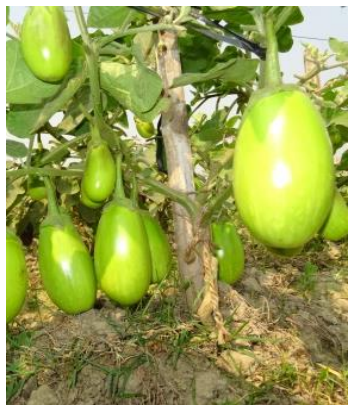

BARI Hybrid Begun-4

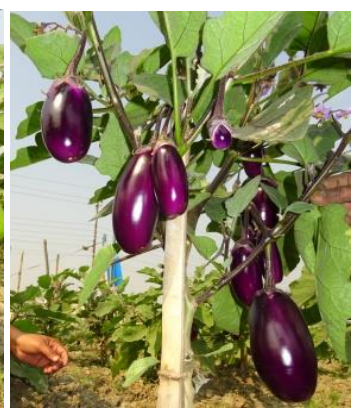

Hybrid 5x216

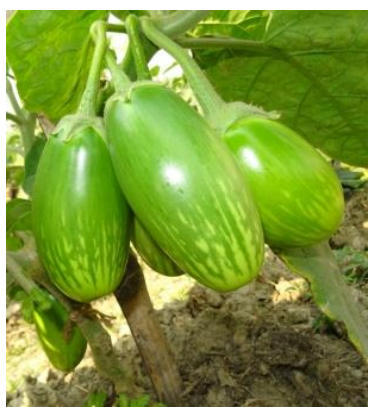

Hybrid $21 \times 11$

Fig. 1. Morphological differences among eggplant cultivars in Bangladesh

TABLE 1. MORPHOLOGICAL CHARACTERISTICS OF POPULAR EGGPLANT CULTIVARS IN BANGLADESH

\begin{tabular}{|c|c|c|c|c|c|c|c|c|c|c|}
\hline $\begin{array}{l}\text { Test } \\
\text { parameters }\end{array}$ & \begin{tabular}{|c} 
BARI Begun- \\
4
\end{tabular} & \begin{tabular}{|c} 
BARI Begun- \\
6 \\
\end{tabular} & \begin{tabular}{|c} 
BARI Begun- \\
8 \\
\end{tabular} & \begin{tabular}{|c} 
BARI Begun- \\
10
\end{tabular} & SM233 & SM275 & \begin{tabular}{|c|} 
BARI Hybrid \\
Begun-2
\end{tabular} & \begin{tabular}{|c|}
$\begin{array}{c}\text { BARI Hybrid } \\
\text { Begun-4 }\end{array}$ \\
\end{tabular} & Hybrid 5x216 & Hybrid $21 \times 11$ \\
\hline Earliness & Early & Medium & Medium & Medium & Early & Medium & Early & Early & Early & Early \\
\hline $\begin{array}{l}\text { (Days to } 1^{\text {st }} \\
\text { harvest) }\end{array}$ & $100-103$ & $105-108$ & $105-108$ & $105-108$ & $100-103$ & $105-108$ & $100-103$ & $100-103$ & $100-103$ & $100-103$ \\
\hline Fruit shape & $\begin{array}{l}\text { Medium long, } \\
\text { cylindrical } \\
\text { with round } \\
\text { end }\end{array}$ & Oval & $\begin{array}{l}\text { Long, } \\
\text { cylindrical } \\
\text { with round } \\
\text { end }\end{array}$ & $\begin{array}{l}\text { Long, } \\
\text { cylindrical } \\
\text { with flat end }\end{array}$ & $\begin{array}{l}\text { Elongate with } \\
\text { round end }\end{array}$ & Oval & $\begin{array}{l}\text { Oblong with } \\
\text { round end }\end{array}$ & $\begin{array}{l}\text { Oblong with } \\
\text { round end }\end{array}$ & $\begin{array}{l}\text { Oblong with } \\
\text { round end }\end{array}$ & $\begin{array}{l}\text { Oblong with } \\
\text { round end }\end{array}$ \\
\hline Fruit color & $\begin{array}{l}\text { Glossy } \\
\text { uniform black } \\
\text { purple }\end{array}$ & Light green & $\begin{array}{l}\text { Uniform } \\
\text { purple }\end{array}$ & $\begin{array}{l}\text { Shiny dark } \\
\text { purple }\end{array}$ & $\begin{array}{l}\text { Uniform } \\
\text { black purple }\end{array}$ & $\begin{array}{l}\text { Green with } \\
\text { white stripe at } \\
\text { bottom }\end{array}$ & $\begin{array}{l}\text { Uniform light } \\
\text { purple }\end{array}$ & Light green & $\begin{array}{l}\text { Uniform } \\
\text { purple }\end{array}$ & $\begin{array}{l}\text { Green with } \\
\text { white stripe at } \\
\text { bottom }\end{array}$ \\
\hline $\begin{array}{l}\text { Fruit length } \\
(\mathrm{cm})\end{array}$ & $17-18$ & $10-12$ & $26-28$ & $28-30$ & $17-18$ & $10-12$ & $14-15$ & $10-12$ & $12-14$ & $12-13$ \\
\hline $\begin{array}{l}\text { Fruit } \\
\text { diameter }(\mathrm{cm})\end{array}$ & $3.7-4.2$ & $8-9 \mathrm{c}$ & $3.7-4.2$ & $4.0-4.5$ & $3.7-4.2$ & $8-9$ & $5.0-5.5$ & $5.0-5.5$ & $6.0-6.5$ & $5.0-5.5$ \\
\hline $\begin{array}{l}\text { Individual } \\
\text { Fruit weight } \\
\text { (g) }\end{array}$ & $100-110$ & $230-250$ & $130-140$ & $140-150$ & $100-110$ & $230-250$ & $130-140$ & $100-110$ & $130-140$ & $100-110$ \\
\hline $\begin{array}{l}\text { Fruit } \quad \mathrm{no} / \\
\text { plant }\end{array}$ & $45-50$ & $17-20$ & $25-30$ & $22-25$ & $50-55$ & $15-18$ & $22-25$ & $45-50$ & $33-35$ & $40-45$ \\
\hline $\begin{array}{l}\text { Yield/ plant } \\
(\mathrm{kg})\end{array}$ & $4.5-5.0$ & $4.0-4.2$ & $3.8-4.0$ & $4.0-4.2$ & $4.5-5.0$ & $4.0-4.2$ & $4.0-4.2$ & $4.0-4.2$ & $4.0-4.2$ & $4.0-4.2$ \\
\hline
\end{tabular}

Crude fiber is an important item for the human body and we got it within $1.01-2.48 \%$, whereas. [40] got 0.65 to $1.54 \%$, which is similar to our study. In the case of ash, the range was $0.37-0.62 \%$ whereas $[17,35,38]$ got similar ash content in a different cultivar with $0.3 \%$ to $0.7 \%$.

Protein is a vital nutrient for any living organism, which was $0.85-1.54 \%$ in this study, while $[17,35,38]$ got the protein content 0.11 to $1.2 \%$. In this study it was estimated that the range of fat was $0.02-0.4 \%$, which was a little bit similar to that of other researchers i.e. [40] analyzed the fat content in different eggplant types reporting values ranging from 0.03 to $0.04 \%$.

Now a day, consumers are so much concern about the low carbohydrates, while in general carbohydrate in eggplant is 5.96 to $7.92 \%$, which was analyzed by [40]. In this study, it was estimated at $4.27-6.63 \%$.
According to USDA reported by [18], the suggested energy from eggplant is $25.0 \mathrm{kcal}$, whereas it was $19.59-32.1 \mathrm{kcal}$ in this study. [65] got the energy amount was $33.6 \mathrm{kcal}$ in eggplant.

Sugar is another body concern item for the human. In general, everybody is interested to take a low amount of sugar, while eggplant assures that low amount. [18] mentioned $3.53 \%$, while [65] mentioned $3.04 \%$. In our study, it was 0.48-1.38, which was much lower.

In case of mineral content range of popular eggplant

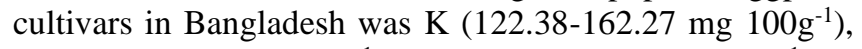
$\mathrm{Na}\left(4.06-8.51 \mathrm{mg} 100 \mathrm{~g}^{-1}\right), \mathrm{Ca}\left(26.62-48.33 \mathrm{mg} 100 \mathrm{~g}^{-1}\right), \mathrm{P}$

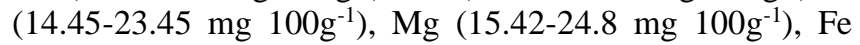
(0.91-5.0 mg 100g-1), Zn (0.22-0.57 mg 100g-1), Mn (0.25-

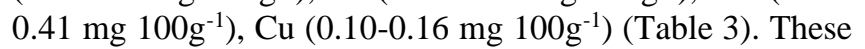
findings are more or less similar withe findings of $[15,36$, 40]. 
TABLE 2. NUTRITIONAL COMPOSITION OF 10 POPULAR EGGPLANT CULTIVARS IN BANGLADESH

\begin{tabular}{|c|c|c|c|c|c|c|c|c|c|c|c|}
\hline Test parameters & $\begin{array}{c}\text { BARI } \\
\text { Begun-4 }\end{array}$ & $\begin{array}{c}\text { BARI } \\
\text { Begun-6 }\end{array}$ & $\begin{array}{c}\text { BARI } \\
\text { Begun- } 8\end{array}$ & $\begin{array}{c}\text { BARI } \\
\text { Begun-10 }\end{array}$ & SM233 & SM275 & $\begin{array}{c}\text { BARI } \\
\text { Hybrid } \\
\text { Begun-2 } \\
\end{array}$ & $\begin{array}{c}\text { BARI } \\
\text { Hybrid } \\
\text { Begun-4 }\end{array}$ & $\begin{array}{c}\text { Hybrid } \\
5 \times 216\end{array}$ & $\begin{array}{c}\text { Hybrid } \\
21 \times 11\end{array}$ & Range \\
\hline Moisture content (\%) & 94.87 & 92.15 & 93.27 & 91.39 & 92.17 & 93.49 & 93.86 & 92.81 & 94.31 & 92.51 & $91.39-94.87$ \\
\hline Crude fiber $(\%)$ & 1.92 & 1.01 & 2.48 & 1.89 & 1.53 & 1.33 & 1.50 & 1.72 & 1.19 & 1.74 & $1.01-2.48$ \\
\hline $\operatorname{Ash}(\%)$ & 0.47 & 0.37 & 0.62 & 0.61 & 0.42 & 0.50 & 0.42 & 0.50 & 0.38 & 0.50 & $0.37-0.62$ \\
\hline Protein $(\%)$ & 1.05 & 1.04 & 1.54 & 1.38 & 1.02 & 1.12 & 0.85 & 1.42 & 0.95 & 1.38 & $0.85-1.54$ \\
\hline Fat $(\%)$ & 0.19 & 0.03 & 0.05 & 0.02 & 0.04 & 0.07 & 0.40 & 0.17 & 0.13 & 0.19 & $0.02-0.4$ \\
\hline Carbohydrate (\%) & 4.73 & 6.63 & 4.27 & 4.94 & 6.05 & 5.72 & 5.20 & 4.61 & 6.27 & 4.91 & $4.27-6.63$ \\
\hline Energy (Kcal) & 19.59 & 30.07 & 24.69 & 32.1 & 29.84 & 24.39 & 24.88 & 27.61 & 21.89 & 28.91 & $19.59-32.1$ \\
\hline Sugar $(\%)$ & 0.83 & 1.38 & 0.51 & 0.87 & 0.72 & 0.63 & 0.48 & 1.06 & 0.66 & 0.66 & $0.48-1.38$ \\
\hline
\end{tabular}

TABLE 3. MiNERAL CONTENT OF 10 POPULAR EGGPLANT CULTIVARS IN BANGLADESH

\begin{tabular}{|c|c|c|c|c|c|c|c|c|c|c|c|}
\hline Test parameters & $\begin{array}{c}\text { BARI } \\
\text { Begun-4 }\end{array}$ & $\begin{array}{c}\text { BARI } \\
\text { Begun-6 }\end{array}$ & $\begin{array}{c}\text { BARI } \\
\text { Begun- } 8\end{array}$ & $\begin{array}{c}\text { BARI } \\
\text { Begun-10 }\end{array}$ & SM233 & SM275 & $\begin{array}{c}\text { BARI } \\
\text { Hybrid } \\
\text { Begun-2 } \\
\end{array}$ & $\begin{array}{c}\text { BARI } \\
\text { Hybrid } \\
\text { Begun-4 }\end{array}$ & $\begin{array}{c}\text { Hybrid } \\
5 \times 216\end{array}$ & $\begin{array}{c}\text { Hybrid } \\
21 \times 11\end{array}$ & Range \\
\hline $\mathrm{K}\left(\mathrm{mg} 100 \mathrm{~g}^{-1}\right)$ & 131.20 & 142.55 & 152.75 & 154.91 & 142.63 & 134.53 & 143.73 & 162.27 & 122.38 & 155.44 & $122.38-162.27$ \\
\hline $\mathrm{Na}\left(\mathrm{mg} 100 \mathrm{~g}^{-1}\right)$ & 4.14 & 4.79 & 6.54 & 7.23 & 7.32 & 8.51 & 4.89 & 5.32 & 4.90 & 4.06 & $4.06-8.51$ \\
\hline $\mathrm{Ca}\left(\mathrm{mg} 100 \mathrm{~g}^{-1}\right)$ & 30.27 & 48.33 & 31.78 & 33.93 & 45.93 & 33.94 & 35.74 & 30.28 & 47.59 & 26.62 & $26.62-48.33$ \\
\hline $\mathrm{P}\left(\mathrm{mg} 100 \mathrm{~g}^{-1}\right)$ & 14.45 & 20.67 & 21.09 & 23.45 & 18.26 & 19.37 & 21.94 & 15.91 & 18.46 & 20.62 & $14.45-23.45$ \\
\hline $\mathrm{Mg}\left(\mathrm{mg} 100 \mathrm{~g}^{-1}\right)$ & 19.30 & 18.21 & 15.42 & 21.40 & 20.69 & 24.80 & 17.67 & 21.40 & 21.61 & 19.30 & $15.42-24.8$ \\
\hline $\mathrm{Fe}\left(\mathrm{mg} 100 \mathrm{~g}^{-1}\right)$ & 1.44 & 1.35 & 1.50 & 1.86 & 1.60 & 1.17 & 1.40 & 1.65 & 5.00 & 0.91 & $0.91-5.0$ \\
\hline $\mathrm{Zn}\left(\mathrm{mg} 100 \mathrm{~g}^{-1}\right)$ & 0.22 & 0.45 & 0.56 & 0.57 & 0.36 & 0.42 & 0.47 & 0.49 & 0.36 & 0.52 & $0.22-0.57$ \\
\hline $\operatorname{Mn}\left(\mathrm{mg} 100 \mathrm{~g}^{-1}\right)$ & 0.37 & 0.36 & 0.40 & 0.25 & 0.33 & 0.41 & 0.30 & 0.29 & 0.26 & 0.32 & $0.25-0.41$ \\
\hline $\mathrm{Cu}\left(\mathrm{mg} 100 \mathrm{~g}^{-1}\right)$ & 0.15 & 0.14 & 0.12 & 0.14 & 0.14 & 0.13 & 0.16 & 0.14 & 0.10 & 0.14 & $0.10-0.16$ \\
\hline
\end{tabular}

Ascorbic acid (mg 100g- (Fig 2) and anthocyanin $\left(\mathrm{mgC} 3 \mathrm{GE} 100 \mathrm{~g}^{-1}\right)$ (Fig 3) ranges was 6.57-17.21 and 6.3178.51 , respectively. In the case of ascorbic acid content the findings was 55 and $64 \mathrm{mg} 100 \mathrm{~g}^{-1}$ by [43], [50], respectively. range was higher than that of the findings of [14], [16], [45]. While the anthocyanin content in other researcher's

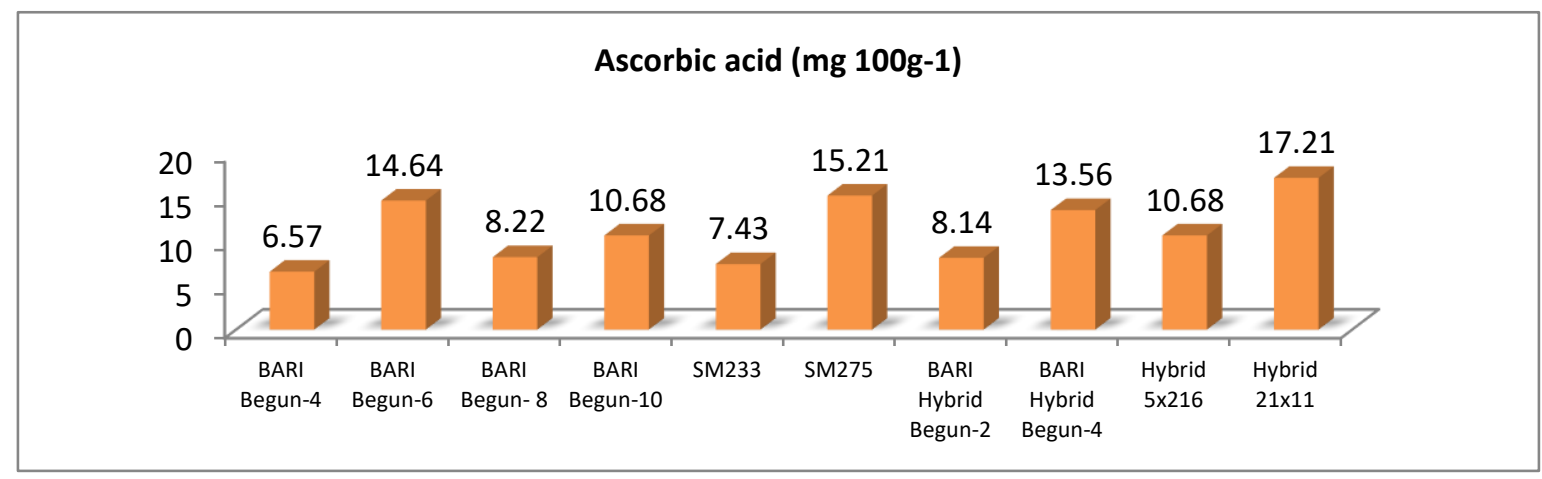

Fig 2. Ascorbic acid (mg 100g-1) content of 10 popular eggplant cultivars in Bangladesh

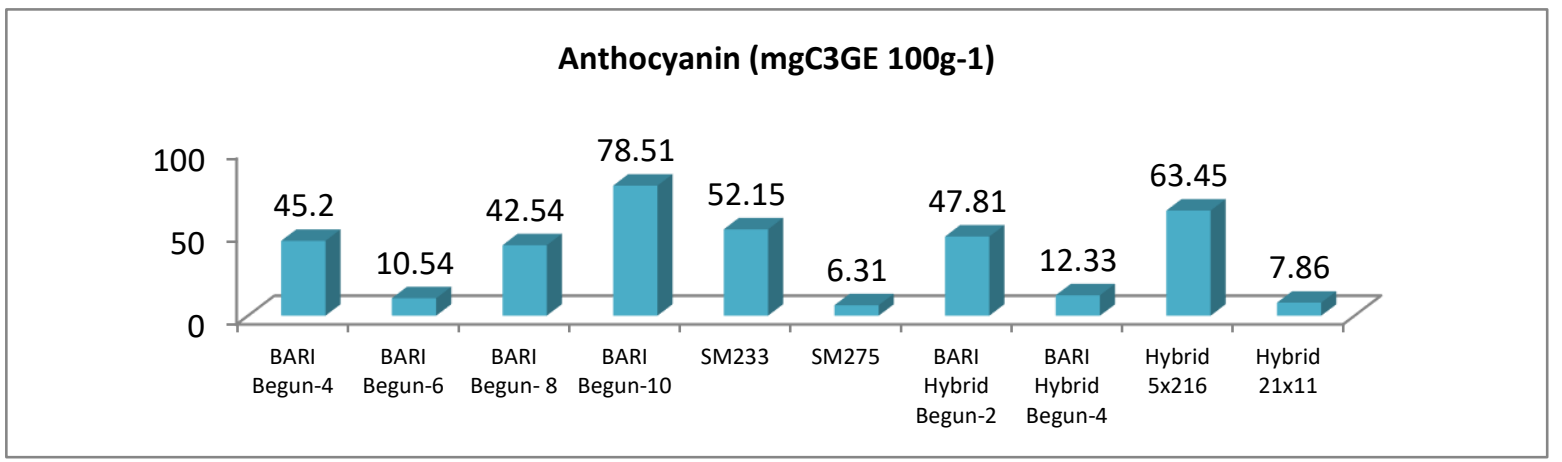

Fig 3. Anthocyanin (mgC3GE 100g-1) content of 10 popular eggplant cultivars in Bangladesh

\section{Health benefits of different nutrients contain in} eggplant

Eggplants are a rich source of nutrients and their contents

(Table 4) which all desirable mainly for body growth and development, to the refurbishment of worn-out materials and also provide a shield. Eggplant is the complete set of minerals, vitamins, nutritional fiber, protein, anti-oxidants, along with some phytochemicals that having scavenging 
activities [41], [67]. The eggplant has superb medicinal effects on different disorders like burns, warts, inflammatory infections, gastritis, stomatitis, and arthritis [24].

TABLE 4. NUTRIENTS AVAILABLE FROM 1 CUP OF EGGPLANT AND DAILY REQUIREMENTS [65]

\begin{tabular}{l|l|l}
\hline Nutrients & $\begin{array}{l}\text { Amount in 1 cup of } \\
\text { eggplant cubes }\end{array}$ & $\begin{array}{l}\text { Daily } \\
\text { requirements for } \\
\text { adults }\end{array}$ \\
\hline Energy (kilocalories) & $\begin{array}{l}33.6 \\
8.29, \text { of which 3.04 are } \\
\text { sugar }\end{array}$ & $1,000-3,000$ \\
Carbohydrate (g) & 2.4 & 130 \\
Fiber (g) & 10.6 & $22.4-33.6$ \\
Magnesium (mg) & 14.4 & $310-420$ \\
Phosphorus (mg) & 117 & $700-1,250$ \\
Potassium (mg) & 13.4 & 4,700 \\
Folate & 8.93 & 400 \\
Choline (mg) & 21.1 & $400-550$ \\
Beta carotene (mcg) & No data \\
\hline
\end{tabular}

It has been known that anthocyanin has a significant role against diabetes, neuronal problems, cardiovascular disorders, and cancer as well. Eggplants are the rich source of anthocyanin compounds, besides their coloring functions. Purple eggplant has a high amount of nasunin compound in their flesh that consumption of such purple eggplant helps against lipid peroxidation and ROS accumulation which occur due to a high level of iron in cells [9]. Anthocyanins present in the skin of eggplant rise serum antioxidant volume and support against heart illness by decreasing LDL (low-density lipoprotein) oxidation. Anthocyanin in peels of brinjal seems a vital part in stopping overweightness by plummeting serum triglyceride and cholesterol and increasing high-density lipoprotein (HDL) cholesterol and decreasing serum triglyceride level [53]. Moreover, they are also helpful in ulcer treatment and vision [20], [68].

Extracts from brinjal have an extra toxic result on cancer cells than on normal cells [2]. Fiber of eggplant helps in digestion by removing toxins and harmful materials from our stomach thus reducing stomach and colon cancer [18]. Chlorogenic acid also shows anticarcinogenic functions by making apoptosis in many human cancer cells, such as leukemia and lung cancer cells [62]. A major phenolic compound chlorogenic acid, found in fruit skin [46] which works as an anti-obesity, anti-inflammatory, anti-diabetic agent and also have cardio-protective functions [44].

As carotenoids cannot be synthesized by our bodies, they should be taken into our diet. Carotenoid-rich foods consumptions are strongly related to reducing the hazard of some types of cancer [32]. Carotenoid-rich eggplant diet can reduce this problem in such countries [25].

Glycoalkaloids present in eggplant own anti-cancer actions. Naturally happening aglycone compound (solasodine) decreases human lung cancer cells in vitro [59]. They also have anti-inflammatory functions and also beneficial to lower blood cholesterol [19]. The phytonutrients maintain brain health via protecting its cell contrary to the obliteration of free radical cells. Compounds present in the eggplant have also the ability to avoid the brain tumor.

The $\mathrm{Fe}$ in eggplant has the ability to pact with premenstrual syndrome, amenorrhea, and antenatal anemia. [6], [10], [11], [31]. Eggplant is also known as a Fe chelator that is suggested particularly for pregnant females, lactating mothers, and teenagers females specifically. The researcher pointed out those patients with Fe deficiency in their body must include eggplant, especially Turkey berry, Thai eggplant, and cherry eggplant for good results [5], [47]. It is also found out that dry eggplants are beneficial in the treatment of stomach bloating, gas, and treat piles, while the fresh fruits consumption strength bones, controls diabetes, prevents paralysis, and helpful in teeth related problems [10], [31]. Eggplants are a rich source of magnesium, manganese, potassium, and copper that are important for healthy bones.

Moreover, the matured fruits of eggplant are employed against stomach troubles, compress for swellings, and splintered nipples [39], [61]. The fruits are important in the treatment of various disorders like asthma, dysuria, dysentery, high blood pressure, and also to cure osteoporosis, arthritis, diabetes and bronchitis, heart diseases and strokes [54], [55]. Juice extracted from roots and leaves of brinjal are used to cure skin diseases, cough, otitis, anorexia, toothache, burns, general stimulant, piles, inflammation, intestinal foot pain, throat and stomach difficulties [33], [39], [54].

\section{Nutrients available from 1 cup $(100 \mathrm{~g})$ of eggplant and daily requirements}

A serving of eggplant can provide at least $5 \%$ of a person's daily requirement of fiber, copper, manganese, B-6, and thiamine. It also contains other vitamins and minerals. Besides, eggplants are a source of phenolic compounds that act as antioxidants. Antioxidants are molecules that help the body eliminate free radicals - unstable molecules that can damage cells if they accumulate in large amounts. Foods that contain antioxidants may help prevent a range of diseases. Among the antioxidants in eggplants are anthocyanins, including nasunin, lutein, and zeaxanthin. The following table shows the nutrients in 1 cup, or about $96 \mathrm{~g}$, of cooked eggplant cubes. It also shows how much of each nutrient a person needs each day. However, people's requirements vary, depending on age and sex.

\section{CONCLUSION AND RECOMMENDATION}

Eggplant is an economically important vegetable of the Solanaceae family with a significant foundation source of numerous quantities of therapeutic, pharmaceuticals, and nutraceuticals compounds. It is a rich source of abundant nutrients and their contents which all desirable mainly for body growth and development, to the refurbishment of worn-out materials and also provides a shield. In Bangladesh, there are several types of eggplants are available, amongst them ten eggplant cultivars were evaluated for morphologically and nutritionally and got the information regarding the nutritional composition which is very much useful for human body growth and development. A restricted sum of research was performed to explored health maintain compounds present in eggplant besides antioxidant and ascorbic acid. Additionally, primary metabolites, like amino acids and phenolic compounds, mainly overlooked. Needless to say, eggplant is a rich source of various valuable bioactive components that must be recognized and more research would be carried out to recognize the nutritive and pharmacological worth of eggplant in real words. So we can say eggplant is one of the world's healthiest foods. 


\section{ACKNOWLEDGEMENT}

The authors would like to thank the Olericulture Division, Horticulture Research Center, Bangladesh Agricultural Research Institute, Gazipur, Bangladesh for the support and allowing this research study, also thanks to the Vegetable Research Technology Section, Institute of Food Science and Technology, Bangladesh Council of Scientific and Industrial Research, Dhaka, Bangladesh for their kind support regarding the chemical composition analysis of eggplant.

\section{REFERENCES}

[1] Abdel-Aal ES, Hucl P (1999). A rapid method for quantifying total anthocyanins in blue aleurone and purple pericarp wheat. Cereal Chem 76(3):350-354.

[2] Afshari F, Serah H, Hashemi Z.S, Timajchi M, Olamafar E, Ghotbi L, Asadi M, Elyasi Z, and Ganjibakhsh M. 2016. The cytotoxic effects of eggplant peel extract on human gastric adenocarcinoma cells and normal cells. Mod Med Lab J., 1: 42-48.

[3] Anonymous. 1995. Agro-climatatrological data. Agromet Division, Bangladesh Meteorological Department, Joydebpur, Gazipur. pp. 3565.

[4] AOAC (1998). Official Methods of Analysis. Association of Official Analytical Chemist. Maryland, AOAC International.

[5] Asiedu-Addo S. 2014. Turkey berry: The wonderful medicinal plant. Daily Graphic Online. Thursday, 16th January, Retrieved 29th July, 2015, graphic.com.gh/15850-turkey-berry-the-wonderful-medicineplant.html.

[6] Bhaskar B, Ramesh KP. 2015. Genetically modified (GM) crop face an uncertain future in India: Bt Brinjal Appraisal - A perspective, Annals of Plant Sciences 4(2): 960-975.

[7] Caguiat XGI, Hautea DM. 2014. Genetic diversity analysis of eggplant (Solanum melongena L.) and related wild species in the Philippines using morphological and SSR markers, Sabrao J Breed Genet. 46(2): 183-201.

[8] Cao G, Sofic E, Prior RL. 1996. Antioxidant capacity of tea and common vegetables, J. Agr. Food Chem., 44: 3426-3431.

[9] Casati L, Pagani F, Braga PC, Scalzo RL, Sibilia V. 2016. Nasunin, a new player in the field of osteoblast protection against oxidative stress. J. Funct. Foods., 23: 474-484.

[10] Cassidy A, Mukamal KJ, Liu L, Franz M, Eliassen AH, Rimm E.B. 2013. High anthocyanin intake is associated with a reduced risk of myocardial infarction in young and middle-aged women. Circulation., 127(2): 188-196.

[11] Chong M. 2005. Perception of the visit and benefits of Bt eggplant by Indian farmers. J. Risk Res., 8(7): 617-634.

[12] Dias JS. 2011. World Importance, Marketing and Trading of Vegetables. Acta Horticulturae, Vol. 921: 153-169.

[13] Doner LW, Hicks KB (1981). High-performance liquid chromatographic separation of ascorbic acid, erythorbic acid, dehydroascorbic acid, dehydroerythorbic acid and diketogluconic acid. Anal Biochem 115(1):225-230.

[14] Durust N, Sumengen D, Durust Y (1997). Ascorbic acid and element contents of foods of Trabzon (Turkey). J Agr Food Chem 45(6):2085 2087.

[15] Ekholm P, Reinivuo H, Mattila P, Pakkala H, Koponen J, Happonen A, Hellstrom J, Ovaskainen ML (2007). Changes in the mineral and trace element contents of cereals, fruits and vegetables in Finland. J Food Compos Anal 20(6):487-495.

[16] Esteban RM, Molla EM, Robredo FJ, Lopez-Andreu FJ (1992). Changes in the chemical composition of eggplant fruits during development and ripening. J Agr Food Chem 40(6):998-1000.

[17] Flick GJ, Burrnette FS, Aung LH, Ory RL, St Angelo AJ (1978). Chemical composition and biochemical properties of mirlitons (Sechium edule) and purple, green and white eggplants (Solanum melongena). J Agr Food Chem 26(5):1000-1005.

[18] Fraikue FB. 2016. Unveiling the potential utility of eggplant: a review, Conference Proceedings of INCEDI., 883-895.

[19] Friedman M. 2006. Potato glycoalkaloids and metabolites: roles in the plant and in the diet. J Agr Food Chem., 54: 8655-8681.

[20] Ghosh D. and Konishi T. 2007. Anthocyanins and anthocyanin-rich extracts: role in diabetes and eye function. Asia Pac J Clin Nutr., 16(2): 200-208.

[21] Golberg G. 2003. Plants: diet and health. The Report of a British Nutrition Foundation Task Force, Blackwell Science, Oxford.,152163.
[22] Gürbüz, N., Uluişik, S., Frary, A., Frary, A., Doğanlar, S. 2018 Health benefits and bioactive compounds of eggplant, Food Chemistry. https://doi.org/10.1016/j.foodchem.2018.06.093

[23] Hyson D. 2002. The health benefits of fruits and vegetables: A scientific overview for health professionals. Wilmington, DE: Produce for Better Health Foundation, p.20.

[24] Im K, Lee JY, Byeon H, Hwang KW, Kang W, Whang WK, Min H. 2016. In Vitro antioxidative and anti-inflammatory activities of the ethanol extract of eggplant (Solanum melongena) stalks in macrophage RAW 264.7 cells. Food Agr Immunol., 27: 758-771.

[25] Kamga RT, Kouame C, Atangana AR, Chagomoka T, Ndango R 2013. Nutritional evaluation of five african indigenous vegetables. Hortic. Res., 21: 99-106.

[26] Kantharajah AS, Golegaonkar PG (2004). Somatic embryogenesis in eggplant. Sci Hortic-Amsterdam 99(2):107-117. Kashyap V, Kumar SV, Collonnier C, Fusari F, Haicour R, Rotino

[27] Kashyap V, Kumar SV, Collonnier C, Fusari F, Haicour R, Rotino GL, Sihachakr D, Rajam MV (2003). Biotechnology of eggplant. Sci Hortic-Amsterdam 97(1):1-25.

[28] Kays SJ, Dias JCS. 1995. Common names of commercially cultivated vegetables of the world in 15 languages. Economic Botany, 49(2): $115-152$

[29] Kays SJ. 2011. Cultivated vegetables of the world: a multilingual onomasticon. Wageningen Academic Pub. doi:10.3920/978-90-8686$720-2 /$

[30] Korkmaz AI, Akgul H, Sevindik M, Selamoglu Z. 2018. Study on determination of bioactive potentials of certain lichens. Acta Alimentaria, 47(1): 80-87.

[31] Krisban S. 2013. 8 excellent reasons to eat more eggplant. Care 2 healthy living. Retrieved from www.care2.com/greenliving /8-greatreasons-to-eat-eggplant-html

[32] Linnewiel-Hermoni K, Khanin M, Danilenko M, Zango G, Amosi Y, Levy J, Sharoni Y. 2015. The anti-cancer effects of carotenoids and other phytonutrients reside in their combined activity. Arch. Biochem. Biophys., 572: 28-35.

[33] Mak G. 2013. Health benefits of Aubergine. Retrieved from www.healthbenefitstimes.com on 22nd October, 2015.

[34] Manach C, Scalbert A, Morand C, Remesy C, Jimenez L (2004). Polyphenols: food sources and bioavailability. Am J Clin Nutr 79(5):727-747

[35] Maroto JV (2002). Horticultura Herbacea Especial. 5th Ed. Ediciones Mundi-Prensa. Mexico. pp. 481-495 p.

[36] Mohamed AE, Rashed MN, Mofty A (2003). Assessment of essential and toxic elements in some kinds of vegetables. Ecotox Environ Safe 55(3):251-60.

[37] Mullie P, Clarys P. 2011. Association between cardiovascular disease risk factor knowledge and lifestyle. Int J Food Sci Nutr., 2(10): 1048.

[38] Munoz de Chavez M, Chavez A, Roldan J, Ledesma J, Mendoza E, Perez-Gil F (1996). Tablas de valor nutritivo de los alimentos de mayor consumo en Mexico. 2nd Ed. Editorial Pax. Mexico, 54 p.

[39] Murray MT. 2004. The Healing power of herbs: The enlightened person's guide to the wonders of medicinal plants (2nd ed.) United States of America, Random House Incorporated.

[40] Nino-Medina, G., D. Muy-Rangel, A. Gardea-Bejar, G. GonzalezAguilar, B. Heredia, M. Baez-Sanudo, J. Siller-Cepeda, R. Velez De La Rocha. 2014. Nutritional and Nutraceutical Components of Commercial Eggplant Types Grown in Sinaloa, Mexico. Not Bot Horti Agrobo, 2014, 42(2):538-544. DOI: 10.1583/nbha4229573

[41] Noda Y, Kaneyuki T, Igarashi K, and Mori A. 2000. Antioxidant activity of nasunin, an anthocyanin in eggplant peels. Toxicology., 148(2-3): 119-123.

[42] Ozgur MU, Sungur S (1995). Third order derivative spectrophotometric determination of ascorbic acid in fruits and vegetables. Talanta 42(11):1631-1640.

[43] Papanga G, Miller N, Rice-Evans CA (1999). The polyphenolic content of fruit and vegetables and their antioxidant activities. What does a serving constitute? Free Radical Res 30(2):153- 162.

[44] Plazas M, Lopez-Gresa MP, Vilanova S, Torres C, Hurtado M, Gramazio P, Andujar I, Herraiz FJ, Belles J.M, Prohens J. 2013. Diversity and relationships in key traits 38 for functional and apparent quality in a collection of eggplant: fruit phenolics content, antioxidan activity, polyphenol oxidase activity, and browning. J Agr Food Chem., 61: 8871-8879.

[45] Prohens J, Rodriguez-Burruezo A, Raigon MD, Nuez F (2007). Total phenolic concentration and browning susceptibility in a collection of different varietal types and hybrids of eggplant:implications for breeding for higher nutritional quality and reduced browning. J Am Soc Hortic Sci 132(5):638-646

[46] Prohens J, Whitaker BD, Plazas M, Vilanova S, Hurtado M, Blasco M, Gramazio P, Stommel JR. 2013. Genetic diversity in 
morphological characters and phenolic acids content resulting from an interspecific cross between eggplant, Solanum melongena, and its wild ancestor (S. incanum). Ann Appl Biol., 162: 242-257.

[47] Putra G. 2011. Nutrition is a key to health. Retrieved from www.nutrient.net 28th August, 2015.

[48] Quebedeaux B, Eisa H. 1990. Horticulture and human healthcontributions of fruits and vegetables-proceedings of the $2 \mathrm{nd}$ international-symposium on horticulture and human health alexandria, va. 2-5 november 1989-preface.

[49] Raigon MD, Prohens J, Munoz-Falcon JE, Nuez F (2008) Comparison of eggplant landraces and commercial varieties for fruit content of phenolics, minerals, dry matter and protein. J Food Compos Anal 21(5):370-376.

[50] Sadilova E, Stintzing FC, Carle R (2006). Anthocyanins, colour and antioxidant properties of eggplant (Solanum melongena L.) and violet pepper (Capsicum annuum L.) peel extracts. Z Naturforsch C 61(78):527-535.

51] Sanchez-Castillo CP, Englyst HN, Hudson GJ, Lara JJ, Solano ML, Munguia JL, James WP (1999). The non-starch polysaccharide content of Mexican foods. J Food Compos Anal 12(4):293-314.

[52] Scalbert A, Williamson G (2000). Dietary intake and bioavailability of polyphenols. J Nutr 130(8):2073S-2085S. Singh AP, Luthria D, Wilson T, Vorsa N, Singh V, Banuelos GS,

[53] Seeram NP, Momin RA, Nair MG, Bourquin LD. 2001. Cyclooxygenase inhibitory and antioxidant cyanidin glycosides in cherries and berries. Phytomedicine., 8: 362-369.

[54] Sekara A, Cebula S, Kunicki E. 2007. Cultivated eggplants - origin, breeding objectives and genetic resources, A Review, Folia Horticulture Ann, 19(1): 97-114.

[55] Seneff S, Wainwright G, Mascitelli L. 2011. Nutrition and Alzheimer's disease: The detrimental role of a high carbohydrate diet. Eur. J. Intern. Med., 22(2): 134-140.

[56] Sevindik M, Akgul H, Pehlivan M, Selamoglu Z. 2017. Determination of therapeutic potential of Mentha longifolia ssp. longifolia. Fresen Environ Bull., 26(7): 4757-4763.

[57] Sevindik M, Rasul A, Hussain G, Anwar H, Zahoor MK, Sarfraz I, Kamran KS, Akgul H, Akata I, Selamoglu Z. 2018. Determination of anti-oxidative, anti-microbial activity and heavy metal contents of Leucoagaricus leucothites. Pakistan journal of pharmaceutical sciences, 31(5 (Supplementary)): 2163-2168.

[58] Sevindik M. 2019. The novel biological tests on various extracts of Cerioporus varius. Fresenius Environmental Bulletin, 28(5): $3713-$ 3717.

[59] Shen KH, Hung JH, Chang CW, Weng YT, Wu MJ, Chen PS. 2017. Solasodine inhibits invasion of human lung cancer cell through downregulation of miR-21 and MMPs expression. ChemicoBiological Interactions., 268: 129-135.

[60] Sihachkr D, Chaput M.H, Serraf L, Ducreux G. 1993. Regeneration of plants from protoplasts of eggplant (Solanum melongena L.). In: Bajaj, Y.P.S. (Ed.), Biotech in Agri and Forestry, Plant Protoplasts and Genetic Engineering. Springer, Berlin., 108-122.

[61] Small E. 2009. Top 100 food plants; the world's most important culinary crops. Canada, Ottawa, Ontario. NRC Research Press.

[62] Tajik N, Tajik M, Mack I, Enck P. 2017. The potential effects of chlorogenic acid, the main phenolic components in coffee, on health: a comprehensive review of the literature. Eur. J. Nutr., 56: 2215-2244.

[63] United States Department of Agriculture (USDA) (2014). USDA National Nutrient Database for Standard Reference. http://www.nal.usda.gov/fnic/foodcomp/search.

[64] Vavilov, N. 1928. Proc. Fifth International Congress of Genetics New York, Pp. 342- 369.

[65] Ware, M. RDN. 2019. Eggplant health benefits and tasty tips. Medical News

Today. https://www.medicalnewstoday.com/articles/279359\#nutrition

[66] Wargovich MJ. 2000. Anticancer properties of fruits and vegetables. HortScience., 35(4): 573-575.

[67] Whitaker BD, Stommel JR. 2003. Distribution of Hydroxycinnamic acid conjugates in fruit of commercial eggplant (Solanum melongena L.) cultivars. J Agr Food Chem., 51(11): 3448-3454.

68] Yousuf B, Gul K, Wani AA, Singh P. 2016. Health benefits of anthocyanin and their encapsulation for potential use in food systems: A review. Crit Rev Food Sci Nutr., 56: 2223-2230.

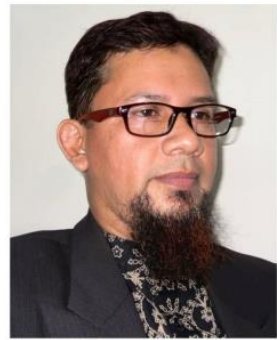

AKM Quamruzzaman born in Dhaka, Bangladesh and got $\mathrm{PhD}$ degree in Horticulture major with Vegetables Breeding From Bangabandhu Sheikh Mujibur Rahman Agricultural University (BSMRAU) in 2011. At present he is currently employed as PRINCIPAL SCIENTIFIC OFFICER at Olericulture Division, BARI, Gazipur, Bangladesh. As a vegetable scientist, he is the principal breeder of Solanaceous and Cucurbitaceous vegetables research. He developed more than 25 vegetables varieties and published more than 60 scientific articles Dr. Quamruzzaman is an active member of American Society for Horticultural Science (ASHS), Bangladesh Society for Horticultural Science (BSHS), Plant Breeding and Genetics Society of Bangladesh (PBGSB) and also serving as project investigator of FAO, AFACI, WordVeg, NATP, SACP-IFAD.

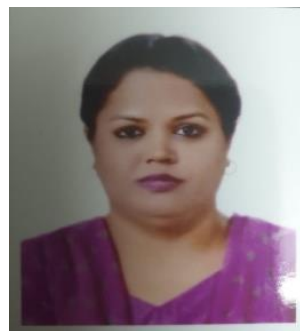

Anjumanara Khatun born in Dhaka Bangladesh and got Master's Degree in Botany, major with Plant Tissue Culture from Dhaka University in 1993 and completed Honor's degree in Botany from Dhaka University. At present she is currently employed as SENIOR SCIENTIFIC OFFICER at Vegetable Research Technology Section, Institute of Food Science and Technology, Bangladesh Council of Scientific and Industrial Research (BCSIR), Dhaka, Bangladesh. As a vegetable scientist, she is working on the research to discover, develop, evaluate new products and published 20 scientific articles. She is an active member of Bangladesh Botanic Society, life member of Bangladesh Association for Plant Tissue Culture, JAIKA and Dhaka University Alumni association.

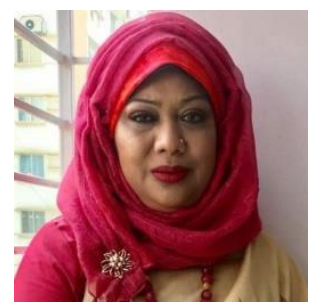

Ferdouse Islam born in Naogaon, Bangladesh and got $\mathrm{PhD}$ degree in Horticulture major with Vegetables production From BAU in 2009. At present he is currently employed as CHIEF SCIENTIFIC OFFICER and at Olericulture Division, BARI, Gazipur, Bangladesh. She is the head of vegetables research at her institute, developed 15 vegetables varieties and published more than 30 scientific articles.

Dr. Islam is an active member of BSHS, BAS and KIB and also serving as project coordinator of FAO, AFACI, WordVeg, NATP. 